9 Закон Эстонии о дорожном движении от 14.07.2017 г. Доступ из: http://robopravo.ru/matierialy_dlia_skachivaniia\#ul-id-4-35. Дата обращения: 04.03.2020.

10 Незнамов А., Наумов В. Модельная конвенция о робототехнике и искусственном интеллекте. Правила создания и использования роботов и искусственного интеллекта 2017. Доступ из: http://robopravo.ru/modielnaia_konvientsiia. Дата обращения: 01.03.2020.

11 Архипов В., Наумов В. Концепция закона о робототехнике. Доступ из: http://robopravo.ru/proiekty_aktov. Дата обращения: 02.03.2020.

\title{
ROBOTIC ARTIFICIAL INTELLIGENCE TECHNOLOGIES IN THE ASPECT OF LEGAL REGULATION
}

\author{
(C) 2020 Deltsova Natalia Veacheslavovna \\ Phd in Juridical Sciences, Associate Professor \\ Samara State University of Economics \\ E-mail: natdel@mail.ru
}

Keywords: artificial intelligence, robotic system, legal regulation, information technologies.

The article is devoted to the formation of legal regulation of artificial intelligence and robot technologies in the Russian Federation. The existing regulations in this area and project legislation are considered Proposals for changing the legislation are presented.

УДК 343

Код РИНЦ 10.00.00

\section{О ПРОБЛЕМАТИКЕ ОГРАНИЧЕНИЙ, СВЯЗАННЫХ С ГОСУДАРСТВЕННОЙ ГРАЖДАНСКОЙ СЛУЖБОЙ В ТАМОЖЕННЫХ ОРГАНАХ РОССИЙСКОЙ ФЕДЕРАЦИИ}

\author{
(c) 2020 Джапарова Диана Алиевна* \\ студент \\ Самарский государственный экономический университет \\ E-mail: diana24101998@mail.ru
}

Ключевые слова: ограничения государственной гражданской службы в таможенных органах, проблематика подчиненности и подконтрольности, право на служебный рост, судимость государственного гражданского служащего таможенных органов.

Настоящая статья посвящена рассмотрению проблематики ограничения подчиненности и подконтрольности в случае наличия близкого родства/свойства государственных гражданских слуцент.

* Научный руководитель - Паулов Павел Александрович, кандидат юридических наук, до- 
жащих таможенных органов; осуществления государственным гражданским служащим своих полномочий при наличии судимости.

Одним из основополагающих условий продуктивного осуществления таможенными органами своих функций является наличие четкой и однозначной нормативной базы, в частности определяющей ограничения, применяемые к гражданским служащим.

Служба в таможенных органах - вид государственной службы граждан РФ, осуществляющих профессиональную деятельность по реализации функций, прав и обязанностей таможенных органов Российской Федерации.

Исходя из смысла п. 3 ст. 55 Конституции Российской Федерации, права и свободы гражданина могут быть ограничены в мере, необходимой для сохранения основ конституционного строя, прав других лиц, обеспечения безопасности государства 1.

Обширный список запретов и ограничений гражданских служащих таможенных органов обусловлен спецификой осуществляемой ими деятельности, деятельности от лица государства, ставящей одной из своих главнейших целей реализацию антикоррупционной политики государства и компетентное, непредвзятое осуществление сотрудниками таможенных органов своих полномочий.

Одним из наиболее сложных в своей реализации представляется ограничение, обозначенное сразу двумя Федеральными законами, а именно п. 5 ч.1 ст. 16 Федерального закона "О государственной гражданской службе Российской Федерации"2 и ч.5 ст.7 Федерального закона "О службе в таможенных органах Российской Федерации"з, суть которого состоит в невозможности принятия гражданина на государственную гражданскую службу и осуществления уже работающим гражданским служащим своих полномочий в случае наличия близкого родства или свойства при соподчиненности и подконтрольности одного родственника другому. Данное ограничение направлено на реализацию принципа профессионализма и компетентности, отраженного в п.4 ст.4 Федерального "О государственной гражданской службе Российской Федерации" , представляющего собой в данном контексте непредвзятость и принятие объективных решений государственными служащими, без намека на субъективизм, вызванный близким родством/свойством со своим подчиненным.

При стандартной ситуации, когда родственники уже замещают должности разных уровней, реализация вышеуказанной нормы не представляет собой сложности. Однако, как быть в ситуации, когда вначале близкие родственники замещают должности одного уровня, неподчиненные и неподконтрольные друг другу, а спустя время одного из них представляют к повышению и возникает конфликт интересов?

Нормативно не регламентирован вопрос изменения служебного состояния при прямом повышения одного из служащих, состоящем в близком родстве или свойстве. Представляется справедливым, что право на служебный рост не должно быть ограничено данным основанием. Исходя из анализа рассмотренной ситуации, наиболее рациональными являются следующие варианты разрешения данной коллизии:

1)перевод на иную должность гражданской службы лица, которое становится непосредственно подчинено или подконтрольно повышаемому родственнику;

2)предоставление повышаемому служащему иной должности в другом структурном подразделении таможенного органа. 
Вышеизложенные варианты требуют консенсуса служащих, исходя из чего, необходимость разработки механизма обеспечения служебного роста имеет существенный характер 4 .

Следующим аспектом нечеткой регламентации является п.2 ч.1 ст. 16 Ф3 №79-Ф3. В рассматриваемом пункте обозначено ограничение, распространяющееся как на кандидатов, претендующих на замещение должности государственной гражданской службы, так и на действующих должностных лиц. Суть его заключается в исключении возможности осуществления гражданской службы в случае осуждения лица к наказанию, ведущему к невозможности исполнения должностных обязанностей, а так же наличия непогашенной и неснятой судимости.

Исходя из буквального толкования данной нормы права, следует, что должностное лицо, осужденное к наказанию, не препятствующему осуществлению должностных обязанностей, может продолжать осуществление своих полномочий или же претендовать на их осуществление. Необходимо отметить, что п.8 ч.1 ст.18 этого же Федерального закона обязует лицо не совершать поступки, порочащие его честь и достоинство, что в соотношении с вышерассмотренной правовой нормой образует коллизию.

Уголовно-процессуальное законодательство в ст.114 УПК РФ предусматривает наличие возможности отстранения от осуществления занимаемой должности в случае необходимости и при наличии постановления судьи 5, которое направляется по месту работы подозреваемого/обвиняемого. Отстранение от занимаемой должности влечет за собой возможность получения лицом ежемесячного пособия.

Погашение / снятие судимости аннулирует все правовые последствия и приравнивает гражданина к несудимому, а следовательно дает возможность претендовать на осуществление государственной гражданской службы в таможенных органах.

Таким образом, законодательство в сфере рассмотренных ограничений государственных гражданских служащих таможенных органов должно подлежать корректировке и приведению к возможности однозначного толкования, дабы исключить правовые коллизии.

1 Конституция Российской Федерации. (Принята всенародным голосованием 12.12.1993) // Собрание Законодательства РФ. - 03.03.2014. - № 9. Ст. 851.

2 Федеральный закон от 27.07. 2004 года N 79-Ф3 (ред. от 19.12.2016) "О государственной гражданской службе Российской Федерации" (Собрание законодательства Российской Федерации, 2004, N 31, ст. 3215; 2017, N 15, ст. 2139)

3 Федеральный закон от 21.07.1997 N 114-Ф3 (ред. от 16.12.2019) "О службе в таможенных органах Российской Федерации"

4 Таможенный контроль : учеб. пособие для студентов вузов / С.Н. Ревина, П.А. Паулов, Д.В. Борякин. - Самара : Изд-во Самар. гос. экон. ун-та, 2018. - 1 электрон. опт. диск. - Систем. требования: процессор Intel с тактовой частотой 1,3 ГГц и выше ; 256 Мб ОЗУ и более ; MS Windows XP/Nista/7/10 ; Adobe Reader ; разрешение экрана 1024x768 ; привод CD-ROM. - Загл. с титул. экрана. - № гос. регистрации: 0321900387

5 Уголовно-процессуальный кодекс Российской Федерации от 18.12.2001 № 174-Ф3 (ред. от 18.02.2020) // Собрание законодательства РФ. - 24.12.2001. - № 52 (ч. І). - ст. 4921. 


\title{
PROBLEMS OF CONTROL AND SUBORDINATION OF STATE CIVIL SERVANTS OF CUSTOMS AUTHORITIES
}

\author{
() 2020 Japarova Diana Alievna \\ Student \\ Samara State University of Economics \\ E-mail: diana24101998@mail.ru
}

Keywords: restrictions of the state civil service in the customs authorities, problems of subordination and control, the right to career growth, criminal record of a state civil servant of customs authorities.

This article is devoted to the problem of implementing the restriction of subordination and control in the case of a close relationship / property of state civil servants of customs authorities; exercise of the powers of a public civil servant if they have a criminal record.

УДК 334.72

Код РИНЦ 06.00.00

\section{ДОКТРИНА СОВРЕМЕННОГО РОССИЙСКОГО ПРАВА О КВАЛИФИКАЦИИ СОГЛАШЕНИЯ ОБ ОКАЗАНИИ ЮРИДИЧЕСКОЙ ПОМОЩИ}

\author{
(C) 2020 Дорофреева Юлия Александровна \\ кандидат юридических наук, доцент \\ Самарский государственный экономический университет \\ E-mail: log1612@yandex.ru
}

Ключевые слова: адвокат, соглашение об оказании юридической помощи, доктрина гражданского права.

В статье дан анализ места соглашения об оказании юридической помощи d системе договоров, освещены подходы к определению указанного соглашения в качестве самостоятельного вида договора и (или) в качестве разновидности отдельных видов договоров (услуги, поручение).

Статус адвоката как лица, осуществляющего квалифицированную правовую помощь, создает особые отношения между ним и доверителем. Именно для выполнения адвокатом задачи защиты прав доверителя, закон установил специальный режим предоставления информации (адвокатский запрос), ее сохранности (адвокатская тайна), а также определил способ оформления отношений доверителя и адвоката - соглашение об оказании юридической помощи. Указанное соглашение можно рассматривать как рассматривать как самостоятельный вид договора, либо как разновидность договора возмездного оказания услуг.

В пользу того, чтобы соглашение об оказании юридической помощи - отдельный вид договора, не подпадающий под классификацию договоров, представленных второй ча- 